\title{
THE LEGAL APPROACH TO CRIME AND CORRECTION
}

\author{
JohN Barker WaItE*
}

The assigned subject of this paper-the legal approach to crime and correction-is cryptic at best. Max Beerbohm might have called it inenubilous. Hence, the writer has arbitrarily assumed that it raises the problem of what law-makers ought to do about crime and correction. That might cover a multiplicity of included problems: Who are the makers of law, for example? On what theory and with what purpose in mind should they define particular acts as criminal? What should be included? How should the fact of forbidden action and the identity of the actor be determined? What consequences ought wisely to be imposed on the actors who are discovered? In short, it might encompass the whole field of criminal law: subjective, procedural, and punitive.

But the writer has no intention herein of struggling with the whole field. The makers of law, for example, need not be discussed, though at another point, some comment will be made on some judge-made rules. Indeed, as the writer hopes to make clear, the judicial attitude toward crime is considerably more closely related to the amount of crime committed than is legislative enactment.

Similarly, the problems of substantive law can also be ignored, for two reasons: In the first place, the writer presumes that "approach" to crime connotes chiefly what can be done to reduce its frequency. But no appreciable amount of crime today can be attributed to insufficiency, uncertainty, or indefiniteness in what the law makes criminal. Hence, need to discuss substantive phases of the law is at once eliminated. ${ }^{1}$ Some minor changes will always be currently desirable, but no material improvement in crime prevention can be accomplished by improvement in the definition of crime. In the second place, whatever can be done in the substantive law field has already been undertaken by an able committee under auspices of the American Law Institute. Its Model Penal Code is setting out the conventional conduct prohibitions with remarkable precision, definiteness, clarity, sufficiency, and readability. A few old prohibitions will be dropped, and a few new ones added. When finished, however, its content will be a thoroughly clear, complete, and satisfactory formulation of substantive criminal law.

* A.B. 1905, Yale University; LL.B. 1907, University of Michigan. Professor of Law Emeritus, University of Michigan; Member, Drafting Committee, American Law Institute, Model Penal Code. Chicf Draftsman, American Law Institute, Youth Correction Act, 194r. Author, Cases on Criminal Law and Procedure (i931), Criminai Law in Action (1934), Prevention of Repeated Crime (1943), Cases on Criminat Law and Enforcement (1947). Contributor to legal publications.

${ }^{1}$ This limitation of the topic to crime reduction also, happily, eliminates need for a disquisition on "insanity" as developed in Durham v. United States, 214 F.2d 862 (D.C.Cir. 1954), a notion so utterly inconsistent with the justifications of existing criminal law-except that of expiation-that if it be adopted, an entirely new legal approach to crime will be required. 
Of the procedural law and its approach to crime, too, little need be said. Supposedly ideal rules of procedure were formulated by a committee of the American Law Institute and presented in 1930.' Some of its provisions have been adopted in a number of states; to a considerable extent, the formulation itself embodied what was already the law in many states. Failures in the procedure of conviction are still regrettably frequent and are, to some extent, responsible for ineffectiveness of prevention. ${ }^{3}$ For the most part, however, these failures are so far attributable to the human beings involved-to the methods of prosecution and defense, to the dilatoriness of attorneys, to the absence of control by judges-that correction by mere alteration and amendment in the procedural law itself is hard to envision. ${ }^{4}$

For such reasons, the writer will limit himself to a discussion of the following three postulates:

I. Mere punishment does not satisfactorily deter crime; it never has, and it cannot be made to do so.

2. The frequency of first crime can be reduced if judges will use their appellate powers to the end of restraining rather than encouraging it.

3. Repetitious criminality can be materially diminished by the use of methods which are more than punishment.

\section{Punishment as a Crime Preventive}

The prospect of physical ill-consequence never has deterred men from seeking gain, whether through crime or otherwise. They took the trails to Santa Fe despite the danger of Comanche torture. They climbed the Chilkoot Pass for gold over the frozen bodies of their predecessors. They went from Dan to Beersheba, between Scylla and Charybdis, across the Gobi Desert. After Henry VIII had executed I6,000 malefactors and hung their bodies in chains for the world to see, still I6,000 more are said to have come undeterred down the paths of crime to his axe and gibbet. The galleys of the Christians were filled with convicts as well as captives;

a Ali Code of Criminal Procedure (1930).

${ }^{3}$ The Uniform Crime Reports for 1956 reveal the commission of 2,563,150 major crimes known to the police. FBI, U.S. Dep'T of Justice, Uniform Crime Reports for the United States 67 (1957). The 1957 report of the Federal Bureau of Prisons shows only 77,029 persons committed to the federal and state prisons by the courts. U.S. Bureau of Prisons, Dep't of JUstice, Federal Prisons 1957, at 98 (1958). That does not mean, of course, that nearly two and a half million criminals went unpunished. Some were sent to juvenile institutions, some only fined, many placed on probation. Nor was each offense the work of a different man. Many were guilty of ten or several times ten crimes before they were caught. But the figures do indicate much about the probability of punishment.

'In 1935, an American Bar Association committee returned a report, Improvement of Personnel in Criminal Law Enforcement, which, among other recommendations, suggested the encouragement of organizations, carefully shielded against bias, partisanship, or political control, to observe and publicize the facts concerning administration of criminal justice, at least where the truth is not otherwise readily discoverable by the general public. When this recommendation came before the Association meeting, Charles A. Beardsley, delegate from California, protested: ". . . as far as our Association is concerned we have troubles enough of our own without advocating the forming of lay organizations to watch what we are doing." Without further discussion, the recommendation was rejected. 6r A.B.A. REP. 330 $(1936)$. 
the horrendous prisons of an earlier day never lacked prisoners sentenced for crime. When Bruno Richard Hauptmann had been executed following the Lindbergh kidnaping, the frequency of kidnapings increased. In I950, the Detroit judges, disgusted with the failure of monetary fines to check automobile traffic offenses, instituted a "crack-down" by way of jail sentences. At the end of six months, they had sent 2,000 drivers to jail-without any diminution in the number of violators brought before them..$^{5}$

Whether men fail to perceive the possibilities of ill-consequence in what they want to do, or, perceiving it, deny the danger to themselves, is for psychology, not law, to answer. The Psalmist suggested the latter, before psychology was a science: "A thousand shall fall at thy side, and ten thousand at thy right hand; but it shall not come nigh thee." But whatever the reason, the threat of punishment for crime committed is not an effective or satisfactory deterrent.

II

The Judicial Function in Crime Prevention

Something, however, does effectively restrain most men from crime; and the most potent influence we know is the innate tendency of human beings to conform with the beliefs of their group. Every normal man is inclined to follow his group conventions, to walk in the ruts of its traditions, to conduct himself in avoidance of group condemnation. It makes the Amish forego use of buttons; Jehovah's Witnesses refuse to fight in war. It leads one man always to wear a tie; encourages another to wear no tie at all. It brings motorists to a stop when traffic lights are red, though there is no power of enforcement in sight. Some years ago, I asked England's director of public prosecutions why the English police did not carry pistols, if only as a matter of self-protection. He considered it amply sufficient explanation to say that weapons were unnecessary, because "our people would be greatly distressed if anyone were to attack an officer."

This tendency to conform is given many names, but its force is recognized: $:^{7}$

If a youngster doesn't take a dollar which just fell out of his mother's purse because he is afraid of getting caught and being thrashed, then we would say that it is his "ego" which limited his possessive urge along the line of "reality consequences." If a youngster doesn't take that dollar, even though he is certain nobody would ever find out, because he would feel bad to do anything which he considers to be a sin, such as stealing, then we would credit his "superego" with the success in impulse control.

\section{It has also been called "conscience." But,}

${ }^{5}$ It is apparent that the frequency of punishment did not represent group condemnation of such activity. There is, as yet, no general hostility toward violation of the speed laws, though continued judicial condemnation could help create it. The results of California's current expcriment should be interesting. See Knight, We Jail Drunken Drivers, Saturday Evening Post, April 26, 1958, p. 31.

- Psalms $91: 7$.

'Tritz Redi \& David Winemsan, Children Who Hate 6i (1951).

${ }^{8}$ I Michel de Montaigne, Essays c. 23. 
the laws of conscience which we claim are born of nature are born of custom; everyone having an inward veneration for the opinions and mores approved and accepted among his own people, and cannot, without very great reluctance, depart from them, nor apply himself to them without applause.

This inhibiting factor, this "superego" or "conscience," if you will, rather than any fear of physical punishment, is what restrains men from conduct which their group chooses to call criminal.

When group conventions are strong and clear, conformity is commonplace. When they are weak or uncertain, individual inhibitions more frequently fail; the "law's" control of conduct is lost. British popular hostility toward interference with their police made police weapons unnecessary, but when the British public was unsympathetic with the customs tax on rum and tobacco, no vigor of enforcement was able effectively to control smuggling. And during our own Prohibition experiment, though drivers might voluntarily stop for traffic lights, men persistently risked heavy penalties to buy unlawful liquor.

Law merely gives formal expression to these group beliefs, sentiments, and customs. They are embodied in statute and are voiced anew in every judicial decision :

The sentence of the law is to the moral sentiment of the public in relation to any offense what a seal is to hot wax. It converts into a permanent final judgment what might otherwise be a transient sentiment. ... In short, the infliction of punishment gives definite expression and a solemn ratification and justification to the hatred which is excited by the commission of the offense, and which constitutes the moral or popular ... sanction.

Further, ${ }^{10}$

the stamping of an act as an offense the commission of which the State will prosecute with unrelenting severity, immediately arouses the feeling that the act is unsuitable, inadmissible, disreputable, contrary to duty ... making the consciousness of right sharper, intensifying the general feeling for right and wrong.

This may be why Soviet law permits judges to deal with certain offenses by "public rebuke."11

But if judges choose to palliate a proved offense, they can wreak havoc with the restraining influence of group belief. They, in theory at least, speak for the group. If judges do not condemn what has been done, the group presumably does not disapprove it. If judges fail to rebuke, the public's disapproval is denied, group condemnation is belied, and the restraints of inhibition are dissipated. Every failure to impose punishment when it is demonstrably due, every judicial refusal to convict when guilt is clear, must appear to the public as a palliation of the offense. This truth acquires maximum importance from the shocking frequency with which appellate judges do refuse the punishment of obviously guilty criminals. Space, of

\footnotetext{
g James Stephen, A History of the Criminal Law of England 79 (1883).

${ }^{20}$ Gustav Aschaffenburg, Crime and Its Repression 259 (1913).

11 Judah Zelitch, Soviet Administration of the Criminal Law 8i (i93i).
} 
course, does not permit the exposition of even a small proportion of such cases, but they may, perhaps, be characterized by a few illustrations.

Some judges appear to have been psychologically obsessed with narrow technicalities, reversing because the charge was theft of a "cow, or animal of the cow kind," and the stolen steer, being male, was not of the cow kind. ${ }^{12}$ Or because, though the jury had convicted on all fifty counts in an accusation of liquor law violation, the defendant's name had been correctly spelled Goldberg in forty-nine counts and Holdberg in the fiftieth." ${ }^{13}$ Or because, though the evidence "would not have proved any fact of the least value in the case had it been properly admitted," its rejection was a breach of rule. ${ }^{14}$

The time was when Sir James Stephen could say of such technicalities that "their tendency was to make the administration of justice a solemn farce."15 Quite possibly, the judges at this time did not really belie the popular feeling about crime and criminals, for the declared law itself was not representative of popular opinion. It was the enactments of a period when the Bishop of Rochester could blandly ask in Parliament the rhetorical question, "What have the masses to do with a law save to obey it?" But law today is supposed to represent the popular beliefs and does, in fact, for the most part, represent them. And what could more flatly belie the public opinion as to murder than the voices of Texas judges in 1945? They reversed a conviction of murder by drowning because the indictment "failed to allege whether the deceased was drowned in water, coffee, tea, or what."16 Again, a year later, they upset conviction of a man who had kicked and stamped an elderly woman to death because he had not been told by the indictment that he did the stamping with his feet. ${ }^{17}$

It is not to be supposed that decisions such as these will encourage anyone to murder, rape, and arson. But judicial indifference toward any serious crime, or repeated judicial pecking at the conventions, ideals, and beliefs which give form to the public conscience must, in time, change men's attitude toward all legal standards of conduct. And judicial decisions do keep pecking away, belittling the wrongfulness of prohibited conduct, palliating it by unnecessary refusal to allow conviction. ${ }^{18}$

\footnotetext{
${ }^{12}$ These and many similar extravagances are noted in Perkins, Absurdities in Criminal Procedure, II IowA L. REv. 297 ( 1926 ).

${ }^{13}$ People v. Goldberg, 287 Ill. 238 , 122 N.E. 530 (1919).

${ }^{14}$ Masters v. Marsh, 19 Neb. 458,27 N.W. 438 (I886).

${ }^{15}$ I STEPHEN, op. cit. supre note 9 , at 284 .

${ }^{10}$ Gragg v. State, 148 Tex. Crim. App. 267,186 S.W.2d 243 (1945).

${ }^{17}$ Northern v. State, 203 S.W.2d 206 (Tex. Crim. App. 1946).

${ }^{18}$ Such judicial attitudes may be a large factor in the present attitude of youth toward crime. If judges do not take it seriously, why should youth? E.g., "Elkhart, Ind.-A youth club rcquiring commission of a crime as a condition of membership was broken today, with three members under sentence. . . . The police have a roster of 30 club members, two thirds of whom have been charged with major crimes." Associated Press, April 9, 1958.

"'Something like 40 high school boys have been involved in larceny from 20 stores,' Ann Arbor Police Chief Caspar Enkeman told the Board of Education. . . . He pointed out that most of the boys come from good homes and can afford to buy what they need. The only comparable thing we have had were recent robberies involving a group of young girls." Ann Arbor (Mich.) News, April 10, 1958. "We've told most of our security officers to stop watching for shoplifters and start watching the clerks"-who are helping themselves to about 500 million a year. Wall Street Journal, April 29, 1958, p.
} 
Attempt to commit crime, for example, has long been recognized as çriminal in itself, even though it fails in its purpose. The only uncertainty is in the problem of what constitutes attempt. In as much as the basic purpose of punishment is threefold-to discourage crime by demonstration of its possible consequence, to prevent it by incapacitation while in prison, and to strengthen individual consciousness of wrong-one might suppose that judges would deal with attempts at crime as seriously as they do with crime itself, wheneyer possible within the provisions of law. But note the type of case wherein they could have done so but, without legal obligation, chose to exonerate the wrongdoer-and thereby to palliate his wrongdoing.

Rizzo, who knew where to lay the finger on a paymaster, Dorio, who could get a car, and Milo and Tomasello, who had pistols, combined assets and went after the money. They missed the paymaster at three places they tried. Then the police, suspicious of their actions, picked them up, and the four were convicted of attempted robbery. The appellate court began its opinion, "The police of the City of New York did excellent work in this case by preventing the commission of a serious crime," but then went on to reverse the conviction of Rizzo, who alone had appealed, and request of the governor the release of the other three from prison. "The law would fail in its purpose if it permitted these three men, whoever or whatever they are, to serve a sentence for a crime which the courts subsequently found and declared had not been committed."19 Just what did Judge Crane think "the law's purpose" to be? And had no crime, no "attempt," been committed in fact?"

Charles Miller, a bit drunk, said to others, "If the people here look at things like that, I'm going to take the law in my hands. I'm going to kill the God-damned nigger." He got his rifle, walked to the field where the "nigger" was picking beans, stopped to load with a high-powered cartridge, and said, "When I shoot a black son of a bitch, I want something that will go through him." Before he got within shooting distance of his victim-while he was 200 yards distant-a local constable jumped him and took his gun away. The jury, the trial judge, and all three judges of the intermediate court thought Miller guilty of a criminal attempt, but the state supreme court judges reversed conviction and released him. ${ }^{21}$

Cosad, Crane, and Shear were charged with forcible rape of a young woman. The jury found them guilty of attempted rape. Here were three men, undeniably dangerous in the sense that every known criminal is presumably dangerous enough to require segregative treatment. Yet, all three went unpunished because appellate judges decided that they had actually succeeded in raping the girl and were not, therefore, technically guilty of an attempt. ${ }^{22}$

1, col. 6. The morally frightening increase of shoplifting by customers is revealed in Manners and Morals -The Shoplifters, Time, May 5, 1958, p. 19, cols. 2, and 3.

${ }^{10}$ People v. Rizzo, 246 N.Y. 334 , 158 N.E. 888 (1927).

${ }^{30}$ The decision was in flat conflict with People v. Sullivan, 173 N.Y. 122,65 N.E. 989 (1903).

${ }^{21}$ People v. Miller, 2 Cal.2d 527, 42 P.2d 308 (1935).

${ }^{23}$ People v. Cosad, 253 App. Div. I04, I N.Y.S.2d '132 (4th Dep't 1937). The defendants were never retried. These cases, and the problem of what legally constitutes attempts, are discussed in Waite, Crime Prevention and Judicial Castistry, 5 Hastrngs L. J. 169 (I954). 
No transcendent authority, no statute nor established precedent compelled any of these decisions. On only one narrow premise of the purpose of law can they, or the others like them, perhaps be justified. If the purpose of punishment were primarily retaliation for injury done, the first two at least were sound; for no injury to anyone occurred. ${ }^{23}$ But to the extent that punishment is intended as a preventive of other crime, whether by deterrence through fear, or by segregation, or by the creation of restraining inhibitions, they completely defeat its purpose.

In another field, judicial toleration of offenders and indifference to their offenses are still more frequent and even more obvious. Appellate judges let known criminals go unpunished not through doubt of their guilt or through some uncertainty in the law, but simply to invest themselves with a power of control over the police. They seek to limit police behavior to what judges themselves, in their assumed wisdom, think proper. The writer concedes the duty of courts to protect individual freedom from improper executive intrusion. If the judges of Nazi Germany, or those of Communist Russia, had possessed the power and the courage to use it, the world might be happier today. But he also realizes that just what constitutes "improper" executive intrusion may be disputable and disputed. He would not himself accept Mr. Justice Murphy's objection to "laying bare to view the intimate personal matters" of a reasonably suspected criminal by methods of photography which can penetrate walls or overcome distance. ${ }^{24}$ But even if one accepts such judicial notions of what is improper in police behavior, still the damage these judges do to social safety by trying to force their will upon the police is out of all proportion to any possible resultant good. They seriously interfere with police efficiency-a matter which is not here in issue. ${ }^{25}$ But also, by their demonstrated indifference to crime, as compared with police behavior, they weaken that "conscience" which is the most effective crime preventive.

Consider, for instance, the 1955 case of People v. Cahan. ${ }^{20}$ Los Angeles had suffered a gang war for control of numbers gambling. Not only had gambling itself become intolerably flagrant, but at least two murders and many vicious beatings were attributable to the struggle. The police were vigorous and apprehended nearly 500 organization underlings. But to break the gang, it was essential to get its top. Compellingly strong suspicion pointed to Charles H. Cahan. Day after day, for many weeks, the police quietly "tailed" him, but he gave away nothing. By tracing the gambler's paper supplies they discovered an office rented to Cahan's brother

${ }^{28}$ Judges are sometimes expressly, as well as subconsciously, motivated by the "tit for tat, tit for tat; kill my dog, I'll kill your cat" notion. E.g., ". . . defendant was found guilty of murder in the first degree and adjudged to be hung in expiation of the crime." State v. Angelina, 73 W. Va. 146, 80 S.E. I4I (I9I3). "... if [New York] does not choose to avenge [the act], it is not for us to step in and do it for them." State v. Carter, 27 N.J.L. 499 (Sup. Ct. 1859).

${ }^{34}$ Goldman v. United States, 316 U.S. I29 (1942).

${ }^{25}$ Last November, a Washington, D. C., deputy chief of police, C. H. Lutz, resigned in frustration at the way police efficiency is "hobbled" by judges. "His vehement remarks drew a second from U. S. Attorney Oliver Gasch. The attorney blasted the enfeebling effects he said recent court decisions have had on local law enforcement." Washington Post and Times Herald, Nov. 21, 1957, p. x, col. 3.

${ }_{44}$ Cal.2d 434, 282 P.2d 905 (I955). 
under an assumed name; but neither Cahan nor his brother came near it. With their chief's consent and approval, the police installed a dictaphone by which they were led to a residence containing another office. A dictaphone here, again with official consent, led them to the evidence needed for Cahan's conviction. There was no doubt of his guilt; but by a four to three decision, the state supreme court repudiated a century of established law, rejected the evidence, and set free that known racketeer and gambler.

Those judges disapproved use of the dictaphones-despite the peculiar difficulties of the case, the need for prompt and effective action, and the authorization by the police chief. Their disapproval suggests ivory-towered sensitivity, rather than awareness of actualities in the active war with crime. ${ }^{27}$ But judges, like everyone else, are privileged to voice an opinion, unsound though it be. The real evil in their decision is the way in which they voiced their disapproval, not what they condemned. As a rebuke to the police for methods of which the judges personally disapproved, they made the public suffer. The ill consequence to social safety was immediate. The police were hampered in their protective efforts. More harmful still, the force of group condemnation, which normally encourages abstention from crime, was belied. $^{28}$

This odd notion of controlling one man's conduct by refusal to punish someone else was not original with that California court. It developed through a striking bit of judicial law-making in the United States Supreme Court. Fremont Weeks, charged with unlawfully sending lottery tickets through the mails, was arrested at a railway station. Officers then went to the house where he lodged, borrowed a key, and searched his room. Because the lottery tickets they found were used in evidence, the Supreme Court reversed conviction. ${ }^{29}$ The search, they said, was "unreasonable" for lack of a warrant; and evidence obtained by unreasonable search, they said, could not be used for conviction.

Again, no transcendent authority required either premise or conclusion. The Constitution does not define what constitutes unreasonableness of search, nor does it make a warrant requisite to reasonableness. What consequences shall follow an

27 "Representative Kenneth B. Keating said today that a survey of wire tapping laws in other countries supported his view that some taps should be authorized here. . . . The overwhelming approval abroad of wirctapping by law enforcement agencies . . . indicates someone is out of step. It is time we got in step, and it is up to Congress to do that job." N. Y. Times, April $13,1958, \$ 1$, p. 58 , col. I. On May 8, I958, he introduced two bills to legalize wire tapping by law enforcement agencies under proper safeguards. H.R. I2393 and 12394, 85th Cong., 2d Sess. (1958). See 104 CoNg. Rec. 7479 (daily ed. May 8, I958). The New York constitutional privilege of police officers to tap the wires of suspected criminals is well discussed in Comment, The 1957 New York Legislation on Wiretapping Problems, 26 Fordham L. Rev. 540 (1957); Comment, Wire-tap Evidence-An Area of Admissibility, 7 DE PaUr. L. Rev. 99 (1958).

${ }^{29}$ Police Chief William H. Parker soon reported that: "While major crime in Los Angeles decreased of 1955. . . . From January I through March 4, 1956, major felony crime in Los Angeles increased $36.6 \%$ over the same period last year." The worst effect, he added, was the increase of dope-peddling and gambling. Speech to the Ebell Club of Los Angeles, March 15, 1956. See also, Parker, The California Crime Rise, 47 J. Crm. L., C. \& P.S. 72I (1957).

${ }^{20}$ Weeks v. United States, 232 U.S. 383 (r914). 
unreasonable search, the Constitution does not say. That the searcher shall not be protected by law from liability is implicit; but nothing more is even suggested. Hence, both in calling the search unreasonable and in forbidding use of the evidence obtained, the Court was no more than voicing the idiosyncratic conclusions of its judges.

That judge-made sule of evidence would probably have fallen into practical oblivion had not the appearance of national Prohibition given it new life. For a time, it was simply ignored by most state courts, rejected by those which did consider it. But even the high courts of justice were touched by the swirling hostilities toward effective enforcement of Prohibition and fear of its possible methods. A dozen state supreme courts, each one sitting in review of a liquor-law conviction, suddenly found theretofore unrecognized merit in the Supreme Court's exclusion notion and adopted it. A half dozen more followed suit in other types of cases. Judicial concepts of "unreasonableness" have gone into meticulous detail, and what was originally a discretionary conclusion has hardened into a rule. Moreover, the postulate of exclusion has been extended from the products of search to what is learned through other methods to which the judges object. ${ }^{30}$

What good this judicial attempt to control the police by indirection accomplishes is at most indeterminable.

That the rule of exclusion and reversal results in the escape of guilty persons is more capable of demonstration than that it deters invasions of right by the police. ... It deprives society of its remedy against one lawbreaker because he has been pursued by another. It protects one against whom incriminating evidence is discovered, but does nothing to protect innocent persons who are the victims of illegal but fruitless searches. The disciplinary or educational effect of the court's releasing the defendant for police misbehavior is so indirect as to be more than a mild deterrent at best. ${ }^{31}$

The evil it produces is evident. Uncountable numbers of known bootleggers, gamblers, gun-toters, thieves, burglars, robbers, counterfeiters, and even killers have gone unpunished simply because appellate judges did not approve the ways in which

${ }^{30}$ The many decisions are discussed, Waite, Police Regulation by Rules of Evidence, $42 \mathrm{MrcH}$. L. REv. 679 (1944); Judges and the Crime Burden, 54 id. at 169 (1955). By the notorious decision in United States v. Mallory, 354 U. S. 449, 455, 456 (1957), the Supreme Court freed a man convicted of vicious rape for no reason except that the police, instead of taking him promptly before a federal commissioncr, as the statutes require, had held him from 2 p.m. until ro p.m.-at which time they tried, but failed, to find one-and from then till morning. There was no pretense of abuse, compulsion, or other unlawful police action. "We cannot sanction this extended delay," said the Court; it has "evil potentialitics." The Court could have castigated the police verbally. It could have advised action against them by the proper authorities, as New York's Court of Appeals asked action by the governor in the Rizzo case, supra note 20. Instead, it chose to rebuke police unlawfulness by release of a vicious criminal. Those justices must, thereforc, have looked on rape as less socially condemnable than the technical misconduct of the police.

${ }^{81}$ Justice Jackson, in Iryine v. California, 347 U.S. 128, 136-37 (1954). Justice Clark added: ". . we do not shape the conduct of local police one whit." Id. at 138 . It is unlikely that judges who follow the exclusion practice will give it up without direction by statute. But it is not inconceivable; the California court in the Cahan case, stipra note 27 , repudiated a hundred ycars of decision in adopting the practice. 
their guilt was discovered. The mere number of escapes is a social evil. ${ }^{32}$ But more socially harmful still is the judicial comparison of police misconduct with vicious crime. By magnifying the one, they minimize and palliate the other. It must be remembered that all such decisions, whether based on procedural technicality or on wish to control the police, are the product of free judicial choice. In thus weighing the evil of crime against the evils of careless procedure or objectionable police action, and declaring crime the less serious, the judges inevitably affect the basic attitude of people toward all types of wrongdoing. Instead of stigmatizing crime as "unsuitable, inadmissible, disreputable," they dull the consciousness of right and they confuse, rather than strengthen, the general feeling for right and wrong.

In thus criticizing judicial attempts to create a right out of two wrongs, the writer is not proposing that judges cease their efforts to protect individuals from executive intrusion and administrative error. On the contrary, he would urge increased effort toward those ends, but by methods less costly and more effective. Though the judiciary lacks direct authority over executive officers, it does have powers of control by indirection more potentially effective than the back-door process of releasing felons. Judicial voicing of direct, publicized, and emphatic rebuke of policemen, commissioners, or incompetent prosecuting attorneys would produce far more certain results. In addition, judicial will, directed to such an end, could materially facilitate the ease and success of direct action by anyone-except caught criminals-whose rights might be invaded. In such methods should lie ample protection.

But certainly, only when judges apprehend the true function of punishment; only when they appreciate the tendency of men to conform with group ideas of right conduct; and only when they strive to clarify, crystallize, and strengthen those group ideas, instead of clouding and belittling them-only then, can society hope for reduction in the amount of first crime committed.

III

\section{Prevention of Repeated Crime}

Repeated crime is a different problem. The forces which might have restrained first crime have been spent; conscience has failed; respect for group opinion has already been lost; punishment once suffered is less fearful than before. For one reason or another, repeated wrongdoing, despite punishment already experienced, is commonplace. It amounts, in fact, to a shocking proportion of all crime committed. Every penitentiary in the country is filled with men who have been in prison from one to ten times before. In those of a dozen states, more than half the inmates are repeaters: ${ }^{33}$

${ }^{32}$ For the escape of gun-toters, see Waite, Public Policy and the Arrest of Felons, 3I Mrch. L. REv. 749 (1933).

${ }^{33}$ Introductory Explanation in ALI Youth CoRrection Authority ACT (1940). "A person once punished for a crime is from a statistical point of view much more likely to commit a crime than one who has never been punished. In other words, a person is more likely to become a second offender 
Of the prisoners in the Eastern Penitentiary of Pennsylvania during one year $67 \%$ had previously been convicted and served time. In the Massachusetts State Prison, $70 \%$ had previously been imprisoned. In New York $80 \%$ of the men sentenced to prison by courts had previous records; 2703 had been arrested 10,766 times. The jail population in Michigan consists of $63 \%$ repeaters; in Washington, D. C., $70 \%$ repeaters; in Louisiana $80 \%$ repeaters.

Specific instances prove little, but are frequently illuminating. In the writer's own files are the records of one man who into thirty-seven years of life had crowded six penitentiary terms; another with nine commitments for such offenses as auto theft, burglary and robbery; another whom five long terms for burglary failed to deter from a sixth burglary, coupled with attempted murder. Every prison file is replete with similar records. The report of the Federal Bureau of Prisons for I956 says succinctly: "Of the I0,I6I prisoners received in Federal institutions under sentence of more than one year, $6,45^{2}$ or 63.5 per cent, had served one or more previous terms in some type or types of correctional institutions...."34 In the field of petty misdemeanors, more than one public nuisance has exceeded the one hundred mark in repeated offenses and repeated punishments. Ogden Nash rhymed a sound philosophy: $:^{35}$

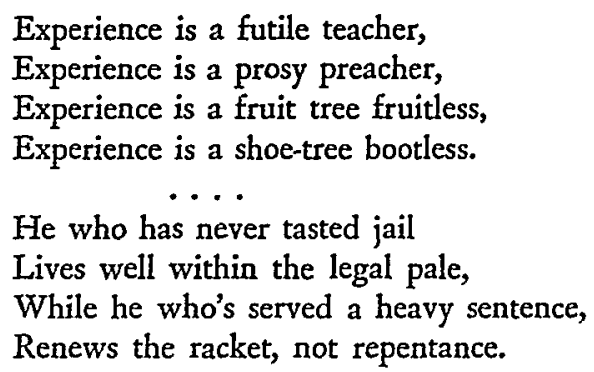

Something more than punishment is needed to pull repeaters from that stage army of offenders and end their interminable march through courts and prison. The basic procedure of punishment-imprisonment-must be continued, both for its effect on the consciences of men, and as a temporary preventive. But men cannot be segregated from society indefinitely, until senility has made them fit for freedom. Prisons enough to hold them all could not be built.

The only conceivable alternative is to seek out, while they are in prison, what makes them behave as other men under similar circumstances do not behave; and to correct that crime-productive factor if found.

Psychiatrists and psychologists say that ... the behavior of human beings is never truly accidental-it follows unalterably the pattern of stimulus and response. It adheres to

than a first offender." Thorsten Sellin, The Criminality of Yourr 102 (1940). Cogent data to the same effect appear in Sheldon \& Eleanor T. Glueck, One Thousand Juvenile Delinquents (I934); Juvenile Delinguents Grown Up (1940); Criminal Careers (1930); and Later Criminat Carezrs (ז937).

34 U.S. Bureau of Prisons, Dep't of Justice, Federat Prisons 1956, at 46 (1957).

${ }^{35}$ Ogden Nash, Experience 20 Let, in I'M a Stranger Here Myself 5 I (1938). 
the principle of cause and effect just as certainly as a chemical reaction does. . . . It has been shown that certain recidivist burglars and automobile thieves are as clearly acting out a neurotically motivated pattern of behavior as are arsonists, kleptomaniacs, or sex offenders. $^{30}$

One need take no stock in the theories of psychology. He may adhere obstinately to a belief in free will and may attribute all crime to machinations of the Devil. Yet, he still must concede that in some men is an opening through which the Devil can reach, while unable to reach the will of others in similar conditions. Even the absolute determinist recognizes that the conduct of recidivism must be determined by some recurrent collocation of conditions. And whatever be the psychologic basis of conduct, it is possible to look for the Devil's opening to the free will of the wrongdoer and seek to close it, or to hunt the idiosyncratic factor which otherwise determines a particular individual's conduct and strike to eliminate it. In one such way or the other, repetition can, to some extent, be ended where imprisonment alone would fail.

Can the cause of crime in particular individuals be found and corrected? Until it is seriously tried, there can be no dogmatic answer. As yet, there is not what can be called proof. But isolated experiments, and a variety of specific instances give reason for strong affirmation, especially in the field of physical causation. ${ }^{37}$

Knowledge of much repetitive crime which seemed somehow related to physical defect led Dr. J. F. Pick to the belief that, as he puts it, "A physical handicap in a young person who in other ways finds it a struggle to understand the social scheme of things may prove to be the trigger of a psychosomatic conflict which in one individual may lead to a gastric ulcer and in another to crime." To validate that belief, he put his skill as a plastic surgeon to work in the penitentiary at Joliet, Illinois. He started with six volunteer patients, all of whom had been in repeated trouble with the law and were "problems" even in the institution:

The first was a young man born with ears pinned on his head by nature in what appeared to be an upside down position. The second was an inmate who early in life suffered a gross deformity of the foot with loss of a heel, in consequence of which he limped badly and found it difficult to hold any job. The third was one who seemingly got along well until he lost his nose. The fourth was born with webbed hands and feet. The fifth was covered from head to foot with hundreds of painful tumors of the neurolipoma type. And the sixth, though conscious of a peculiar looking face, claimed he never had any urge to commit crime until his young son, seven years old, began to shy away and remarked, "Daddy, you look just like a bad man. Why don't you change your face?"

All told, Dr. Pick operated, at their request, on 376 penitentiary inmates. Of the results, he says: "The sociological results cannot for the present be stated in full

\footnotetext{
${ }^{30}$ Manfred S. Guttacheher \& Henry Weihofen, Psychiatry and the Law (I952).

${ }^{37}$ The data and remarks which follow are from unpublished letters to the writer. The necessity and possibility of truly correctional treatment of convicts is discussed in Karpman, Criminal Psychodynamics, 47 J. CRIM. L., C. \& P.S. 8 (1956); Larson, On Rehabilitating Chronic Traffic Offenders, id. at 46.
} 
except to say that only I.07 per cent of the 376 patients operated on have returned to the institution in ro years. This is markedly below the usual percentage." How many more such men could be similarly taken from the stage army of repeaters, how many future crimes could thus be forestalled no one knows, for the simple reason that we have never tried to find out.

Other opportunities for decimating that stage army of repeaters appear in various ways. Castration as a punishment would be universally condemned; as a punishment, it would serve no purpose except vindictiveness. But as a preventive of repetition by a certain class of dangerous personalities it may have high value. The State Training School of Kansas for half a century has had to deal with men, most of whom are of the feeble-minded type, many guilty of forcible rapes, of attacks on children both heterosexually and homosexually, or otherwise sexually dangerous in society. Its onetime superintendent, Dr. Charles C. Hawke, had opportunity to study the effects of castration in $33^{\circ}$ cases. To anyone with only a literary knowledge of eunuchs his incidental conclusions may be startling. The castrate, he found, does not become obese; he does not tend to become hairless; his voice does not change its pitch; he does not become sluggish and lazy, nor morose and vindictive; he does not become sexually incapacitated. But castrates do "lose their excessive sex urge and exhibitionism and are stabilized to the point where they are no longer potential sex criminals." Of one individual, Dr. Hawke says:

He was recommended for operation in 1931. At that time he was $r 8$ years of age. The Board refused to consent to castration and recommended vasectomy instead. This was done, and one month later he again escaped from the institution and raped a small girl in Wichita. Following this episode, the Board recommended castration, which was done. Following this second operation he gave very little trouble in the institution; was paroled about three years later, and later discharged. In $194^{\mathrm{r}}$ he married, moved to Wichita where he obtained employment, and has been a law abiding citizen ever since.

We have no records of any sex crimes committed by our castrated parolees.

In most of the United States, castration as a cure, even when voluntarily consented to, is forbidden by law. In Denmark, on the contrary, it is permitted, and from Denmark, Dr. George Sturup reports that only 3.7 per cent of voluntarilycastrated sex criminals repeat their crimes, as compared with 43 per cent of the uncastrated. ${ }^{38}$

Of specific instances, one finds in a medical journal of urology the record of a man four times convicted of rape and assault with intent to rape. When at last properly studied, he was found to be afflicted with chronic inflammation of the urethra which made sexual desire abnormal. The inflammation allayed by medicine, his conduct changed. ${ }^{39}$

Psychiatrist Harold $H$. Hulbert says of another offender:

\footnotetext{
${ }^{38}$ Time, April 20, 1953, p. 84, col. 2.

so Compare this with a Michigan record: "C.S. after 30 years in prison for four sex offenses, sentenced a fifth time at 59 years of age."
} 
The fellow was irritable, without apparent provocation. He was arrested and fined a few times for assault, then sentenced for attempted murder. In the penitentiary he was so unpredictable in his explosive irritability that he was transferred from security confinement to a prison for insane criminals. There he was treated by "therapeutic neglect" and did not improve. [He had, it later developed, an ulcerated tooth, which he himself pried out with a nail.] . . . . His mouth healed; it was no longer filled with pus. . . . His explosive rages ceased and he slept quietly. He no longer suffered from psychomotor epilepsy; and he ceased to be sullen, dull and touchy. ... I examined him; the traumatic atrophy of the jaw was apparent. There had been ample cause for his rages, his crimes. [He was released.] For twelve years now he has been a quiet worker. He is steady.-Recovered.

The writer has used these cases only as illustrations; there are, of course, many more. Though by themselves they prove nothing, they suggest a great deal. The treatments necessary to put these possibilities into practice, however, would be expensive. But if by such study and corrective treatment the vast bulk of repeated crime were cut by as little as ten per cent, the profit to society, in money alone, would be enormous. Opportunity for some Foundation or other institution with money to spend in the public interest, therefore, lies here-opportunity for outstandingly beneficial service. Its agents could assemble the discoverable data of what has been accomplished in prevention of repetition. They could analyze the information, draw conclusions as to what can or cannot be done, as to the expectable results of one measure or another. They could learn the facilities which now exist and expound what would be needed. They could prepare legislation not only for declaration of ideals, but for creation of the details as well. And they might sell sound proposals to legislatures for real reduction in repeated crime.

What can be done for less merely physical, more especially psychiatric, causation, no one knows, but there are reasons for optimism. Group therapy, for examplediscussion by a group of persons affected by similar psychological troubles, under guidance of a trained psychiatrist-has found enthusiastic advocates for half a century. ${ }^{40}$ It has recently found its way into federal prisons and such progressive state institutions as the California Medical Facility-a branch of the prison system. No precise data as to its effectiveness in preventing repetition have yet been collected, but faith in its value is strong among people who have watched its operation.

Simpler, more specifically-applied methods may likewise so alter an individual's psychology as to change him from a poor social risk to a good one. The report on "Number 64758 " was an instance. On admission "he was antagonistic, resentful, and walked about with a chip on his shoulder. The general impression was of a man with extremely low intelligence, probably mentally defective." $\mathrm{He}$ was, nevertheless, admitted to the prison's school. In fifteen months, he learned what children acquire in four and one-half years of school. "His attitude completely changed; he became cooperative, pleasant and eager to improve himself." As he himself put it:

\footnotetext{
“See Mich. Dep't of Corrections, "Let's Talk It Over," A Program of Social Education
} Throvgh Group Counselling (1958). 
"I won't get into trouble any more because I won't be afraid that people will take advantage of me. I used to feel like a dope, not knowing how to read or write."41

Unfortunately, while the physiological cause of idiosyncratic personality is sometimes apparent, the myriad possible factors in a particular individual's psychological condition are usually difficult of ascertainment. As Dr. Guttmacher, chief psychiatrist of the Baltimore Supreme Court, puts it: "Although great progress has been made in the last half century in analyzing and interpreting behavior, the problem is so complex and our skills are still so incomplete that much of the time we have to. rely on opinion and conjecture rather than on knowledge." Nevertheless, whatever psychiatry can do should be utilized. Only the most timorous of defeatists would deny the wisdom of setting it to work in the forestalling of repetition.

There is more to the problem, however, than the correction of physical or mental causation. Men in prison today learn from their fellows the practical lore of crime -swindles they had not thought of, new methods of safe-cracking, the arts of evasion. But in the arts and skills of honest living, they get little if any help. Yet, sooner or later, each will be released. Each one will go forth into a society where honest livelihood will be more difficult than before, and his capacity to earn it will be less. The accountant's skill will be rusty from disuse; the artisan unversed in the developments of his trade; the laborer too flabby from idleness for a full day's work. Some few will go forth to ease and financial comfort, but a huge majority will return to greater financial stress than before they were imprisoned and to the same friends. who failed before to keep them from crime. It might be said of all these, as a social worker of Cincinnati's House of Correction once put its problem to me: "When prostitutes are sentenced to my institution, we cure them of disease. At the end. of their terms we turn them onto the streets, with no money, no job, no home, no place to sleep. Is it strange that they promptly come back?"

The obvious preventative of return for such reasons is two-fold: First, training while in the penitentiary in more effective capacity for earning an honest living. Then, real and affirmative assistance, financial and otherwise, in earning that living and living honestly after release.

Michigan provides a nonsecurity probationary camp to which young probationers can be accredited, as an escape from the normal surroundings which would probably drive them again into crime and where they are given education in industrial skills and book-learning. ${ }^{42}$ One California institution, too, exercises its prospective parolees in the muscular development needed for the skills they have learned. There is no sound reason why every penitentiary could not give similar intellectual instruction and training in trade skills to every inmate capable of profiting from it. For many, it might be useless, and for others, only an adjunct of further crime. And,

\footnotetext{
¿1 Communication from Bertram Pollens, Senior Psychologist, N. Y. Dep't of Correction.

${ }^{2}$ See Mich. Dep't of Correction Pamphlet No. 4, PREP: Pioneer Readiness for Emplomment Prograx (n.d.); Mich. Dep't of Correction Pamphlet No. 6, Camp Pugslexy (n.d.). These pamphlets. and others carry the legend "printed by Hill Top Trade School," a state corrective institution.
} 
again, it might be expensive, though not necessarily so. ${ }^{43}$ But the reduction in recidivism would more than pay those costs.

After release, if a man is to abstain from further crime, he almost invariably requires assistance-not merely the negative help of being required to keep away from saloons and to report to a supervisor periodically. He comes out of prison usually with no money at his command. If he is to earn his way successfully, someone must initially furnish enough to pay the initiation fees without which some unions will not permit him to work at his trade. Someone must furnish him with the tools a skilled mechanic may need. Though he be no more than an unskilled laborer, someone must furnish him transportation to wherever work is to be found. And someone must provide the cost of mere existence until pay day arrives. ${ }^{44}$

Without such affirmative assistance, the ex-convict is normally doomed to return to prison. The assistance necessary to save him from recidivism, however, like everything else in crime prevention, will require state money. But the total amount conceivably called for would be far less than the cost of his repeated criminalitycost to his victim, cost to the state for arrest, prosecution, and further prison maintenance. Any proper "legal approach" to crime prevention is inescapably bound to establish such positive methods of preventing repetition.

But success in any of these aims will not be attained by the cheap and easy procedure of putting orders on the statute books. Declared law is not active law. Too often, indeed, it begets inaction. It creates a consoling delusion that what ought to be done has been done, and the originally impelling concern becomes quiescent.

The Youth Correction Authority Act proposed by the American Law Institute is an outstanding illustration of such unsatisfied hope. ${ }^{45}$ Its first provision reads: "The purpose of this Act is to protect society more effectively by substituting for retributive punishment methods of training and treatment directed toward the correction and rehabilitation of young persons found guilty of violation of law." It sets up, verbally, an "Authority" empowered and directed to provide for convicts and to do for them everything suggested in the foregoing paragraphs. Its ideas and general provisions were adopted by the legislatures of five states and by Congress. ${ }^{46}$ Unfortunately,

${ }^{43}$ There would be ample market for goods produced by prisoners being trained in trade skills. Statutes in many states do prohibit the sale or other disposition of prison-made goods on the open market. But some of these statutes expressly provide that state institutions shall, so far as possible, buy what they need from prison-operated industries, and others impliedly permit it. Such statutes are noted specifically in John B. Waite, The Prevention of Repeated Crime 62 (I943).

" "Only a thorough sociological and clinical study of the individual repeater can guide us in our selection of rehabilitative measures. This paper attempts to treat the decisive importance of one segment of correctional work: the reintegration of convicted men and women into society by means of proper employment." Frym, The Treatment of Recidivists, 47 J. CRIM. L., C. \& P.S. I (1956). What little is now being done is discussed in John B. Watte, The Prevention of Repeated Crime (I943).

${ }^{45}$ As the writer was one of its original proponents and its chief draftsman, whatever criticism he voices falls directly upon himself.

${ }^{10}$ Cal. Welfare and Inst'Ns Code $\$$ itio; Mass. Ann. Laws cc. IIg, t20 (r951); Minn. Stat. $\$ \$ 242.02$ et seq. (I957 Supp.); Tex. Rev. Crv. Stat. art. 5143C (1957 Supp.); Wis. Stat. c. 54 (I955); 64 Stat. 1085 (1950), 18 U.S.C. $\$ 5001$ et seq. (1952). See Bertram M. BECK, A STUdy of the Youth 
however, and perhaps naïvely, while it created an Authority directed and empowered to do these things, it did not specify within itself the facilities and funds necessary for carrying its purposes into action. It could be enacted, and was enacted, as a declaration of purpose, without making accomplishment of that purpose possible. And because the enacting legislatures failed to implement their stated objectives with necessary money and facilities, the whole idea remains, for the most part, just thata good idea.

That is only an example on a large scale. State statutes are filled with other laudable directives of narrower scope which cannot be carried out because legislatures, satisfied with saying the right thing, furnish no facilities for effectuating what they say. A Michigan statute, for example, provides that boys or girls between the ages of seventeen and nineteen who are found to be addicted to drugs or liquor, who associate with prostitutes, pimps, or other disreputable persons, who are wilfully disobedient, or who "habitually idle away their time" may be committed to the State Corrections Commission for "correctional treatment and care" until the age of twenty-one years; but they "shall be confined and cared for separate and apart from persons committed by courts of criminal jurisdiction." to prevent further and more serious wrongdoing. An excellent statute! Except that it provides no places in which the Commission can confine these young people and no facilities whatever for the "treatment" ordered.

As this was being written, Michigan newspapers reported: $:^{48}$

A group of 22 youthful offenders from Detroit, refused admittance to the Lansing Boys Vocational School, were back at their homes today-authorities hoped. Wayne County yesterday sent a busload of 25 youths sentenced to the school at Lansing. The school found room for three of them, but the remainder were returned to Detroit. The school now has an enrollment of 421 boys against an ideal capacity of 365 and has another 63 on a waiting list.

Careless enactments such as these, good law which speaks well but cannot act by itself, are commonplace in every state.

Law-making is easy. But its objectives take understanding, money, and energy. The conclusion is clear-the wise legal approach to crime and correction, for legislatures and judges alike, is to stop making new law and begin giving effect to existing law.

Authority Program (I95x). See also Tappan, Young Adults Under the Youth Authority, 47 J. Crim. L., C. \& P.S. 629 ( 1957$)$.

${ }^{47}$ Mich. CoMp. LAwS $\$$ 7I2A.2, 7İA.5 (1948).

${ }^{48}$ Ann Arbor (Mich.) News, April 10, 1958. A 1958 legislative change in the name from "Ionia Reformatory" to "Hilltop Academy and Trade School" will have no effect on its capacity; it is but another illustration of satisfying, but unsatisfactory, law-making. 